\title{
Carbon Emission Disclosure in the Proper Rating Company's Annual Financial Statements in Indonesia Stock Exchange
}

\author{
Nurlis, Nurlis \\ Lecture of Accounting Department Mercu Buana University
}

\begin{abstract}
Annual Reporting is a media for companies that initially only report financial aspects, but now also report on social and environmental aspects. The shift in determining the value of this company along with the emergence of issues of natural and environmental damage. Environmental issues are increasing, accounting also evolves by giving birth to the concept of green accounting and sustainability reporting. This study aims to analyze the effect of PROPER, media exposure, company size, profitability and leverage on Carbon Emission Disclosure. The population in this study is a participant company PROPER 2014-2017. The results of this study show that PROPER, Media Exposure, and Profitability have a significant positive effect on Carbon Emission Disclosure, while company size and leverage do not have a significant effect on Carbon Emission Disclosure.
\end{abstract}

Keywords: Carbon Emission Disclosure, PROPER, Media Exposure, Company Size, Profitability, and Leverage. DOI: $10.7176 /$ RJFA/10-12-08

Publication date: June $30^{\text {th }} 2019$

\section{A. INTRODUCTION}

Global warming is a phenomenon that is endless to talk about. In general, global warming is an event caused by an increase in the average temperature of the atmosphere that causes climate change. The increase in temperature comes from increasing greenhouse gas emissions resulting from everyday human activities (Wahyuni, 2011: 4). One of the factors causing the increase in greenhouse gases is, among others, originating from industrial activities. Industrial activities that are currently developing rapidly, turned out to have a negative impact that caused the quality of the environment to decline.

According to data from the world institute report contained in the website hima.pl.ppns.ac.id, Indonesia is in the top 10 as the largest producer of carbon gas in the world. On the page it is written that the total carbon produced in the world is 45.914 billion tons. Indonesia contributes carbon emissions of 2,053 billion tons. This fact makes Indonesia committed to reducing carbon emissions based on Presidential Regulation No. 61 of 2011 article 4 concerning the National Action Plan for Reducing Greenhouse Gas Emissions (RAN-GRK). The first step in reducing carbon emissions is by disclosing carbon emissions in a sustainability report, so that companies can determine emissions targets that must be reduced and determine the strategy for reducing emissions.

Disclosure of carbon emissions in Indonesia is still voluntary, so not all companies disclose information about disclosure of carbon emissions in their reports. This makes research on the factors that influence voluntary disclosure of carbon emissions interesting to study. However, research on disclosure of carbon emissions in companies in Indonesia is also still limited. Previous research has mentioned several factors that influence disclosure of carbon emissions. These factors include having a test result that is still dynamic.

This study, using a framework based on stakeholder theory and legitimacy theory, aims to determine the factors that influence the broad disclosure of greenhouse gas emissions in Indonesia. This study uses content analysis from Choi, et al (2013) which was developed from the Carbon Disclosure Project (CDP). In this measurement there are 18 information regarding carbon emission disclosure which will be measured using the checklist index in this study.

This study uses a sample of companies registered as PROPER participants in 2014-2017. This selection was carried out because PROPER participants were considered to have performed good environmental performance because they were monitored by the Ministry of Environment. In this study, the independent variables that influence the voluntary disclosure of greenhouse gas emissions by companies in Indonesia are PROPER ratings, media exposure, company size, profitability, and leverage

The Corporate Performance Rating Program (PROPER) is one of the efforts of the State Ministry of Environment to encourage company compliance in environmental management through information instruments (menlh.go.ig). PROPER's rating will show that companies have more active levels of the environment and will indirectly have initiatives to voluntarily disclose environmental information, such as disclosing the level of carbon emissions in sustainable reports to inform their performance which investors and the public will indirectly observe.

Media exposure is the exposure of the media as a means of communication, the media can determine whether or not a message is delivered to the target audience or target audience. If the company expands on social media activities in the media, it will indirectly motivate companies to disclose carbon emissions because these companies get more attention from the public because of their activity in carrying out social and environmental 
activities.

Company size is a large scale company and can be measured by the total assets / large assets of the company using the calculation of the total asset logarithm value. Large companies tend to get greater encouragement from stakeholders to disclose carbon emissions compared to small companies. Because large companies want far better quality financial reports by making carbon emissions disclosures in their reports.

Profitability is a ratio used to determine the ability of a company to generate profits. Companies with high profitability will have more ability to pay HR to carry out carbon emissions. so that the higher the profitability of the company the greater the extent of disclosure of carbon emissions.

Leverage is used to determine the level of debt held by the company, the higher the leverage, the more focused the company will be to pay off its debts rather than paying costs to pay HR to disclose carbon emission.

\section{B. FRAMEWORK OF THINKING}

In carrying out business activities, the company must have encouragement from stakeholders. In addition, the company's main goal is to provide prosperity to its stakeholders based on the stakeholder theory put forward by Friedman (1962) who said that the company's main goal is to maximize the prosperity of its owners. One way to provide prosperity for the company owner is to provide satisfaction with the output produced by the company, one of them is by presenting better quality financial reports. A more quality report is a report that has a complete element of elements and makes disclosures in each of its activities in this case, especially the disclosure of carbon emissions.

The disclosure of carbon emissions is also based on the legitimas theory of gaining support with social values and norms from society. Legitimacy theory explains that in maximizing the financial strength of the company for the long term, social responsibility must be expressed in order to obtain legitimacy from social actors in the place of business. Underlying the legitimacy theory is the "social contract" that occurs between companies and communities where companies operate and use economic resources (Ghozali and Chariri, 2007). The company also operates to gain the legitimacy of the community. Companies that disclose carbon emissions in their reports will be observed by external parties including the community, thus the community will assume that the company has taken action that is aware of the importance of environmental sustainability.

With looking rank of PROPER it can show that the company has a more active level of the environment or not. Companies that have a high PROPER rating indirectly will have the initiative to voluntarily disclose environmental information (Ghazali, 2015). Stakeholder theory reveals that disclosure made by good environmental companies will be good news for stakeholders so that it can maintain corporate relations with stakeholders maintained.

Strengthened by the legitimacy theory that the community will highlight companies that have a high PROPER rating that the company has good environmental performance. That way the company will be motivated to carry out carbon emissions disclosures in order to maintain the trust that has been obtained from the public regarding environmental activities, especially regarding the disclosure of carbon emissions.

Companies that actively expose social and environmental activities to the media will tend to have initiatives to make environmental disclosures in this case, especially the disclosure of carbon emissions in their reports. Based on the legitimacy theory of "social contact" companies that are active in the media will get more attention from the public so that they have more pressure to maintain the level of trust that the company has from the community in overcoming environmental problems.

Stakeholder theory also underlies this research that there will be pressure from outside parties to present better quality reports. Because stakeholders according to Ghazali are not only company owners but also investors and the public, including stakeholders. So that the community also has an important contribution in the assessment of higher quality reports.

Large companies will get great pressure from the public and stakeholders have high expectations regarding carbon management practices. To respond to these pressures, the way that companies can take is to make environmental social disclosures, especially regarding carbon emissions, in order to get support from stakeholders and gain legitimacy from the community. Companies with large scale have greater pressure to create better quality sustainability reports. (Pardini, 2013)

Based on legitimacy theory, the community always puts pressure on the company to care about environmental problems. Companies with high profitability are easier to respond to these pressures because companies are able to pay for more resources that can be used to make environmental disclosures. So that the report produced will be more qualified. Companies with good financial condition have the financial ability to make decisions related to the environment. Conversely, companies with poor financial performance focus more on achieving financial goals (Irwhantoko, 2017)

Companies with high leverage will be more focused on paying off liabilities compared to voluntary disclosures. (Prafitri, 2016). Stakeholder theory states that one stakeholder (creditor) tends to pressure companies to prioritize repayment of all forms of debt rather than voluntary disclosures such as disclosure of carbon 
emissions because it will only add to the company's financial burden. The greater the company's leverage, the greater the interests of creditors, making it difficult for companies with large leverage to make carbon emissions disclosures.

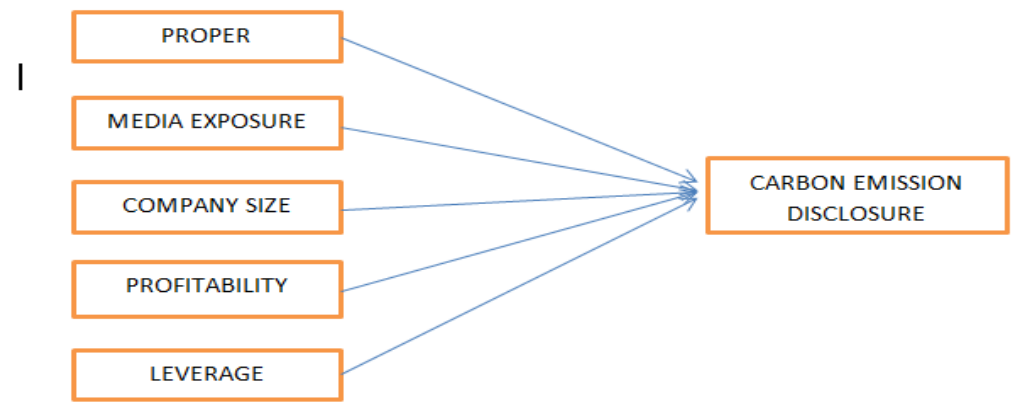

Figure 1 Conseptual Model Of Research

\section{RESEARCH METHODS}

This study uses a quantitative causal descriptive method. This research was conducted to examine the effect of PROPER, Media Exposure, and Company Characteristics on Carbon Emission Disclosure. This study uses a linear regression test. The population in this study was a company registered as a proper participant in 2014-2017 and listed on the Indonesia stock exchange in 2018. The total population was 216 populations. Companies that are used must disclose at least 1 disclosure of carbon emissions and generate profits in the year of research so that the total sample in this study is 105 samples.

Table 1

Variable Operationalization

\begin{tabular}{|c|c|c|c|}
\hline No & Variabel Name & Indicator & Scale \\
\hline 1 & Carbon Emission Disclosure & $\mathrm{CED}=(\Sigma \mathrm{di} / 18)$ & Ratio \\
\hline \multirow[b]{6}{*}{2} & \multirow{6}{*}{ PROPER } & $0=$ not an Ordinal participant & \multirow{6}{*}{ Ordinal } \\
\hline & & $1=$ Very bad / black & \\
\hline & & $2=\mathrm{bad} / \mathrm{red}$ color & \\
\hline & & $3=$ good $/$ blue & \\
\hline & & $4=$ very good / green & \\
\hline & & $5=$ very good $/$ golden color & \\
\hline \multirow[b]{3}{*}{3} & \multirow{3}{*}{ Media Exposure } & Dummy Variabel : & \multirow{3}{*}{ Nominal } \\
\hline & & $1=$ disclose a little & \\
\hline & & $2=$ disclose a lot & \\
\hline 4 & Company Size & SIZE $=$ LN(Size Aset $)$ & Ratio \\
\hline 5 & Profitabilitas & $\begin{array}{l}\text { ROA = Net profit after Tax / Total Asset } \\
\text { Ratio }\end{array}$ & Ratio \\
\hline 6 & Leverage & DER $=$ Total Debt $/$ Total Equity Ratio & Ratio \\
\hline
\end{tabular}

\section{DATA ANALYS}

Based on the results of normality test data using the Kolmogorov-Smirnov test, obtained by the KS value of 1.241 with a significant value of 0.92 . It can be concluded that this study has data that are normally distributed, multicollinearity test also has a tolerance value $>0.10$ or VIF less than 10 . This means that this study does not have a relationship between each independent variable. Based on the results of the Rank Spearman test the Sig. (2-tailed) Unstandardized residual $>0.05$ means that variables are free from heteroscedasticity problems. Autocirrelation test results have also shown that the value of durbin-waston is in the area between du and 4-du so that this study is also free from the problem of autocorrelation.

To find out the truth of the regression test, the coefficient of determination (Adjust R2) is done to find out whether all variables have jointly significant influence on the dependent variable in the F test. Adjust R2 in this regression model has a value of 0.661 which means that $66 \%$ of this regression model influenced by PROPER, Media Exposure and company characteristics while 34\% are influenced by other variables not included in this study. The Adjust R test results can be seen in the following table: 
Table 2

Determination Coefficient Test (R2)

\begin{tabular}{|l|r|r|r|r|}
\hline Model & $R$ & $R$ Square & $\begin{array}{c}\text { Adjusted R } \\
\text { Square }\end{array}$ & $\begin{array}{c}\text { Std. Error of the } \\
\text { Estimate }\end{array}$ \\
\hline 1 &, $823^{\circ}$ &, 677 &, 661 &, 097509 \\
\hline
\end{tabular}

a. Predictors: (Constant), DER, ROA, ME, PROPER, SIZE

b. Dependent Variable: CED

To test whether the hypothesis is accepted or not has been tested hypothetically, the results of the hypothesis test are 3 variables that have an influence on the Carbon Emission Disclosure and 2 variables that have no effect on Carbon Emission Disclosure. To find out the results of the hypothesis test are presented in the following table 3 :

Table 3

T test

\begin{tabular}{|c|c|c|c|c|c|c|}
\hline & & & & oefficients" & & \\
\hline \multirow{2}{*}{\multicolumn{2}{|c|}{ Model }} & \multicolumn{2}{|c|}{ Unstandardized Coefficients } & \multirow{2}{*}{$\begin{array}{c}\text { Standardized } \\
\text { Coefficients } \\
\text { Beta }\end{array}$} & \multirow[t]{2}{*}{$t$} & \multirow[t]{2}{*}{ Sig. } \\
\hline & & B & Std. Error & & & \\
\hline \multirow{6}{*}{1} & (Constant) &,- 425 & .117 & & $-3,620$ &, 000 \\
\hline & PROPER &, 042 &, 016 &, 162 & 2,565 &, 012 \\
\hline & ME &, 232 &, 022 &, 685 & 10,487 &, 000 \\
\hline & SIZE &,$\infty 08$ &, 008 & , 070 & 1,052 &, 295 \\
\hline & ROA &, 273 &, 091 &, 175 & 3,005 &, 003 \\
\hline & DER &, 001 & 011 &, 008 &, 131 & 896 \\
\hline
\end{tabular}

Based on the table above, it can be seen that the Beta value of each variable is positive, meaning that the influential variable has a positive effect. Variables that have an influence on carbon emission disclosure are PROPER, Media Exposure, and Profitability, while Firm Size and Leverage have no effect on carbon emission disclosure.

\section{DISCUSSION}

\section{Effect rank of PROPER to Carbon Emission Disclosure}

Based on the results of the test it can be concluded that PROPER has a positive effect on Carbon Emission Disclosure, this result means that companies that have a high proper rating mean that the company has been active in tackling environmental problems and contributing directly to environmental conservation, therefore, the company will have initiatives to disclose information about the environment, especially carbon emissions in annual reports to inform their environmental performance which will be indirectly observed by external parties. These results are also supported by the legitimacy theory which reveals that there is a tendency for companies that have good environmental performance to conduct environmental disclosures. This is done so that public trust in the company is maintained and the community still gives full support to the company.

This is in line with the results of the Pardini (2013) and Prafitri (2016) study which state that PROPER has an effect on disclosure of carbon emissions. In another study, Ghazali (2015) stated that the PROPER rating had an effect on disclosure of carbon emissions. The results of this study are strengthened by the existence of stakeholder theory which states that companies are not entities that only operate for their own interests, but must provide benefits to stakeholders, namely shareholders, creditors, consumers, suppliers, government, society, (Ghozali and Chariri, 2007: 409). With the PROPER rating that affects disclosure of carbon emissions, it is expected that companies can pay more attention to environmental conditions so that they can be beneficial to stakeholders and the public.

\section{Effect Media Exposure to Carbon Emission Disclosure}

Based on the results of these tests it can be concluded that Media Exposure has a positive effect on Carbon Emission Disclosure. The results of this study are also supported by legitimacy theory, companies that actively expose social and environmental activities to the media will also be active in the disclosure of carbon emissions. Because companies that are active in the media have more attention than the community, and to gain legitimacy from the community, companies are motivated to make carbon emissions disclosures..

This statement is corroborated by the results of Janah's research (2014) that the media positively influences the disclosure of carbon emissions. Ghazali (2015) and Nurdiawansyah (2017) also stated that the media had a positive effect on carbon emissions disclosure. 


\section{Effect Company Size to Carbon Emission Disclosure}

Based on the results of the test it can be concluded that the Company Size does not affect Carbon Emission Disclosure, this result has a meaning that the existence of the size of the company proxied with LN total assets, does not affect to report information about the environment, especially carbon emissions in the annual report. Because large and small companies have the same pressure to make better quality sustainability reports. One of the more quality sustainability reports is more complete with environmental disclosures, especially regarding carbon emissions.

Thus, these results are not in line with the Pardini (2013) study, the results of testing the size of the company have a significant effect on carbon emissions disclosure. Jannah (2014) also states that the size of the company influences the disclosure of carbon emissions. Ghazali (2015) the size of the company has a significant positive influence on carbon emissions disclosure.

\section{Effect Profitabilitas to Carbon Emission Disclosure}

Based on the results of the test it can be concluded that Profitability has a positive effect on Carbon Emission Disclosure, this result means that companies with good financial conditions (high profitability) are able to pay for additional human or financial resources needed for voluntary reporting and disclosure of carbon emissions. The higher the level of profitability, the more the company will be able to voluntarily disclose carbon emissions.

This result is in line with the results of previous research by Cahya (2016), Irwhantoko (2017), and Hermawan (2018) stating that profitability affects carbon disclosure. The results of this study are also supported by stakeholder theory. Gray, et al. (1997) said that the survival of a company depends on stakeholder support and that support must be sought so that the company's activities are to seek that support. The government and the wider community will demand that companies with high profitability make voluntary disclosure reports because the parties consider that the company has the ability to do so and will not be a burden on the company.

\section{Effect Leverage to Carbon Emission Disclosure}

Based on the results of the test it can be concluded that Leverage has no effect on Carbon Emission Disclosure, these results are not in line with the results of previous studies by Hanifah (2017) and Ghazali (2015) which resulted in Leverage having a negative effect on carbon emissions disclosure. Another study from Jannah (2014) states that leverage has a positive effect on carbon emissions disclosure.

This result means that the size of the leverage level does not affect the reporting of information about the environment, especially carbon emissions in the annual report. Because there has been a good relationship between the company and creditors as stakeholders, which has resulted in creditors not paying too much attention to companies making environmental disclosures. So the results of this study are in line with Pratiwi's research (2017).

\section{E. CONCLUSIONS AND SUGGESTIONS}

Based on the results of research on the effect of PROPER, Media Exposure, and company characteristics (Company Size, Profitability, and Leverage) on Carbon Emission Disclosure, it can be concluded that not all variables studied have an effect on Carbon Emission Disclosure. PROPER, media exposure and profitability have a positive influence on carbon emission disclosure while firm size and leverage have no effect on carbon emission disclosure.

In this study the sample used only by companies that become proper participants is expected in future studies to be able to use companies that have high carbon intensity so that they can see whether a high-carbon producer company gets a proper rating that is good or not that should make environmental disclosures regarding carbon emissions. because it has contributed a lot of carbon emissions to the atmosphere. And this study also has a value of R2 of 0.661 so there are still $34 \%$ more variables out of this study. It is expected that other studies can add other variables that can be used as independent variables in future studies.

\section{REFRENCE}

Anggreni, Ni Luh Putu Mila dan I Gusti Ayu Nyoman Budiasih. 2016. "Peran Media Exposure Bagi Pasar Modal Indonesi". Fakultas Ekonomi dan Bisnis Universitas Udayana.

Ardianto, Elvinaro. 2011. "Public Relations dan Corporate Social Responsibility" Jakarta: Kompas Gramedia.

Berthelot, Robert, 2011. Climate change disclosure: An examination of Canadian oil and gas firms. Issues in Social and Enviromental Accounting, Volume 5 No. 1, Pp 106-123.

Brammer, S., Brooks, C. \& Pavelin, S. (2006). Corporate social performance and stock returns: UK evidence from disaggregate measures. Financial Management, 35(3), 97-116

Cahya, Bayu Tri. 2016. "Carbon Emission Disclosure: Ditinjau dari Media Exposure, Kinerja Lingkungan dan Karakteristik Perusahaan Go Publik Berbasis Syariah di Indonesia. STAIN Kudus.

Choi, et al. 2013. "An Analysis of Australian Company Carbon Emission Disclosure" Pacific Accounting Review Vol 25 Iss pp. 58-79 
Dawkins and Fraas, 2011. Coming Clean: The Impact of Enviromental Performance and Visibility on Corporate Climate Change Disclosure. Journal of Business Ethics, Volume 100, 303-322

Deegan, Craig. 2000. "Financial Accounting Theory". McGrow-Hill Australia Pt Limited. Australia.

Dowling, J. and Pfeffer, J. 1975. "Organisational Legitimacy: Social Values and Organisational Behavior”, Pacijic Sociological Review, Vol. 18, pp. 122- 36.

Friedman, Milton. 1962. Capitalism and Freedom. Chicago: University of Chicago Press

Ghazali, Imam dan Rizqi Abdul Majid. 2015. "Analisis Faktor-Faktor yang Mempengaruhi pengungkapan gas rumah kaca Pada Perusahaan di Indonesia”. Fakultas Ekonomika dan Bisnis, Universitas Diponegoro.

Gray, R.H., Dey, C., Owen, D.L., Evans, R. and Zadek, S. 1997. Struggling with the Praxis of Social Accounting. Stakeholders, Accountability, Audits and Procedures. Accounting, Auditing and Accountability Journal, Vol. 10 No. 3, pp. 325-64

Hanifah, Umi. 2017. “Analisis Karakteristik Perusahaan Terhadap Carbon Emission Disclosure dan Pengaruh Carbon Emission Disclosure terhadap Nilai Perusahaan.” Akuntansi Sekolah Pascasarjana Universitas Muhammadiyah Surakarta.

Harahap, Sofyan Syafri. 2005. Perangkat dan Teknik Analisis Investasi di Pasar Modal Indonesia:Yogyakarta.BPFE UGM

Hartono, Jogiyanto. 2008. "Teori Portofolio dan Analisis Investasi”. Yogyakarta: BPFE.

Hermawan, Atang. 2018. "Going Green: Determinants of Carbon Emission Disclosure in Manufacturing Companies in Indonesia". International Journal of Energy Economics and Policy.

Hery. 2017. "Kajian Riset Akuntansi". Jakarta: PT Grasindo.

Hilmawan, Aditya. 2016. "Akuntansi Lingkungan Dinilai Mampu Tingkatkan Laba Perusahaan" www.suara.com di akses pada 30 Maret 2018.

Ikhsan, Arfan. (2008). Akuntansi Lingkungan dan Pengungkapannya. Yogjakarta: Graha Ilmu.

Irwhantoko dan Basuki. 2016. "Carbon Emission Disclosure: Studi pada perusahaan manufaktur di Indonesia". Fakultas Ekonomi dan Bisnis. Universitas Airlangga.

Jannah, Richatul. 2014. "Analisis Faktor-Faktor yang Mempengaruhi Carbon Emission Disclosure Pada Perusahaan di Indonesia (Studi Empiris pada Perusahaan yang Terdaftar di Bursa Efek Indonesia Periode 2010-2012)”. Fakultas Ekonomika dan Bisnis, Universitas Diponegoro.

Kementrian Lingkungan Hidup Republik Indonesia. "PROPER". www.menlh.go.id diakses pada 27 Maret 2018.

Linggasari, 2015. Pengaruh Karakteristik Perusahaan Terhadap Carbon Emission Disclosure. Fakultas Ekonomi dan Bisnis. Universitas Diponegoro.

Luo, et al, 2012. Corporate Incentive to Disclose Carbin Information: Evidence from the CDP Global 500 Report. Journal of International Financial Management \& Accounting, Volume 23 No. 2, 93-120.

Nurdiawansyah. 2017. "Determinan Pengungkap Emisi Karbon Pada Perusahaan Manufaktur di Indonesia". Fakultas Ekonomi dan Bisnis. Universitas Lampung.

Mardina, Salman. 2011. "Perusahaan Harus Pakai Sistem Akuntansi Lingkungan”. www.economy.okezone.com di akses pada 11 Maret 2018.

Pradini, H. S. 2013. "The Analysis of Information Content towards Greenhouse Gas Emissions Disclosure in Indonesia Companies". Fakultas Ekonomika dan Bisnis, Universitas Diponegoro.

Prafiti, Anistia dan Zulaikha. 2016. "Analisi Pengungkapan Gas Rumah Kaca” Departemen Akuntansi Fakultas Ekonomika dan Bisnis Universitas Diponegoro.

Pratiwi, Putri Citra. 2016. "Pengaruh Tipe Industri, Media Exposure dan Profitabilitas terhadap Carbon Emission Disclosure". Fakultas Ekonomi UNP.

Primus, Josephus. 2015. "Penting, Laporan Keberlanjutan Perusahaan sebagai Kewajiban" www.kompas.com diakses pada 6 April 2018.

Putra, Lutfy Mairizal. 2017. "Emisi Karbon Tahun 2017 Diprediksi Akan Pecahkan rekor". www.sains.kompas.com di akses pada tanggal 30 Maret 2018.

R.E. Freeman, Strategic Management: A Stakeholders Approach, Fitman, Boston, 1984, hlm.37.

Republik Indonesia. 2011. Peraturan Presiden No. 61 Tahun 2011tentang Rencana Aksi Nasional Penurunan Emisi Gas Rumah Kaca. Sekretariat Kabinet RI. Jakarta.

Republik Indonesia. 2011. Peraturan Presiden No. 71 Tahun 2011 tentang Penyelenggaraan Inventarisasi Gas Rumah Kaca Nasional. Sekretariat Kabinet RI. Jakarta.

Riyanto, Bambang. (2008) "Dasar-Dasar Pembelanjaan Negara". Yogyakarta: BPFE

Roberts, R.W. 1992. Determinants Of Corporate Social Responsibility Disclosure: An Application Of Stakeholder Theory”, Accounting, Organisations and Society, Vol. 17 No. 6, pp. 595-612.

Setiany, Erna., et, al, 2018. "Environmental Disclosure in Agricurtural Sector and Consumer Goods Anual Report". Vol 7.

Sukma S, Defrina. 2016. “Akuntan Tak Sekadar Bookkeeper, Tapi Juga Pengambil Keputusan" www.news.unair.com di akses pada 11 Maret 2018. 
Uyar et, al, 2013. Association Between Firm : Evidence from Turkish Listed Companies. Intangible Capital, Vol. 9(4), 1080-1112.

Wahyuni, Sri. (2011). “Menghasilkan Biogas dari Aneka Limbah”. Jakarta: PT AgroMedia Pustaka.

Wang et, al, 2013. The Determinants of Corporate Social Responsibility Disclosure. Evidance From China. Vol. 29, No. 6.

Warren, J. 2008. “Carbon Accounting”. E-book : http://www.scotlink.org di akses pada tangal 25 April 2018

Wira, Desmon. 2017. “Analisis Fundamental Saham”. Jakarta: Exceed.

Yadiati, Win”win. 2017. “Kualitas Pelaporan Keuangan: Kajian Teoritis dan Empiris. Jakarta: Kencana.

Yuliana, Nina. 2014. "Media Relations" Yogjakarta: Graha Ilmu.

Zhang,et al. 2013. New technologies reduce greenhouse gas emissions from nitrogenous fertilizer in China. Journal of Accounting Research

www.sahamok.com

www.idx.com

www.kemenlh.co.id

www. hima.pl.ppns.ac.id 